Jurnal Insan Farmasi Indonesia, 3(2) Desember 2020 (217-229)

Amelia Lorensia

p-ISSN 2621-3184 ; e-ISSN 2621-4032

doi: 10.36387/jifi.v3i2.583

\title{
EFEKTIVITAS EDUKASI VIDEO DALAM KELENGKAPAN PENJELASAN CARA PENGGUNAAN MDI DENGAN/TANPA SPACER PADA MAHASISWA FARMASI
}

\author{
Amelia Lorensia ${ }^{1 *}$, Rifaatul Laila Mahmudah ${ }^{2}$, Asrie Dewayani ${ }^{1}$, Nevyta \\ Fitriandasari $^{1}$ \\ 1 Pharmacy Faculty, University of Surabaya, Indonesia \\ ${ }^{2}$ Departement of Public Health, Stikes Majapahit, Indonesia \\ *: amelia.lorensia@gmail.com
}

\begin{abstract}
ABSTRAK
Asma merupakan penyakit kronik yang dapat dicegah dengan pengobatan dengan reliever. Metered Dose Inhaler MDI adalah salah satu penanganan cepat pada asma, tetapi pada penggunaan teknik MDI masih kurang pada pasien dapat menyebabkan pengobatan asma tidak optimal. MDI dengan spacer biasanya direkoemndasikan untuk pasien yang kesulitan menggunakan MDI. Mahasiswa farmasi merupakan bibit dari program studi lanjutan yaitu apoteker yang nantinya akan bertanggung jawab menjelaskan kepada pasien mengenai cara menggunakan MDI dan MDI dengan spacer dengan tepat. Penelitian ini bertujuan untuk mengetahui pengaruh pemberian edukasi dalam bentuk video cara penggunaan inhaler. Penelitian ini penelitian quasi eksperimental menggunakan checklist. Pengambilan sampel dengan metode non random sampling dengan menggunakan teknik purposive. Data akan diolah dengan analisis statistik deskriptif. Sampel penelitian kelompok MDI sebanyak 85 subyek sedangkan kelompok MDI dengan spacer sebanyak 84 orang. Hasil penelitian menujukkan ada perbedaaan kelengkapan penjelasan cara penggunaan MDI $\mathrm{p}=0,000$ dan MDI dengan spacer $p=0,000$ setelah pemberian edukasi video. Jadi dapat disimpulkan edukasi video efektif dalam meningkatkan kelengkapan penjelasan cara penggunaan MDI dan MDI dengan spacer.

Kata kunci: mahasiswa farmasi, edukasi video, metered dose inhaler MDI, spacer

ABSTRACT

Asthma is a chronic disease that can be prevented by treatment with reliever. Metered Dose Inhalers MDI is one of the rapid treatments for asthma, but the use of MDI techniques is still lacking in patients can cause asthma treatment is not optimal. MDI with spacers is usually recommended for patients who have difficulty using MDI. Pharmacy students are the seeds of advanced study programs, namely pharmacists who will be responsible for explaining to patients about how to use MDI and MDI with spacers correctly. This study aims to determine the effect of providing education in the form of videos on how to use inhalers. This study was a quasi experimental study using a checklist. Sampling using the non random sampling method using purposive techniques. Data will be processed with descriptive statistical analysis. The MDI group research samples were 85 subjects while the MDI group with 84 spacers. The results of the study showed that there
\end{abstract}


Amelia Lorensia

p-ISSN 2621-3184; e-ISSN 2621-4032

doi: $10.36387 /$ jifi.v3i2.583

were differences in the completeness of the explanation on how to use MDI $p=$ 0,000 and MDI with spacers $p=0,000$ after giving video education. So it can be concluded that video education is effective in increasing the completeness of the explanation on how to use MDI and MDI with spacers.

Keywords: pharmacy students, video education, metered dose inhaler MDI, spacer

\section{PENDAHULUAN}

Asma merupakan salah satu dari masalah kesehatan mayor di dunia. Kondisi gejala asma yang tidak terkontrol dapat mengurangi kualitas hidup pasien, peningkatan biaya pengobatan, bahkan dapat menyebabkan kematian akibat komplikasi asma. Tujuan dalam terapi asma adalah mencapai kondisi klinis yang terkontrol ${ }^{1}$. Sistem pengiriman inhaler merupakan bentuk penting dari perangkat pemberian obat dalam pengobatan asma, karena memiliki keuntungan pemberian obat langsung ke sistem pernapasan dan efek samping yang lebih sedikit ${ }^{2}$. Pasien asma banyak menunjukkan cara penggunaan yang salah secara signifikan pada semua desain inhaler yang digunakan saat ini, yang sebenarnya dirancang untuk meningkatkan kemudahan penggunaan dalam memberikan efek yang optimal ${ }^{3}$. Hal ini menjadi penyebab utama perawatan suboptimal ${ }^{2}$, sehingga penggunaan inhaler menjadi relatif lebih mahal, jika tidak digunakan dengan benar.

Jika pasien merasa nyaman dengan menggunakan inhalasinya dengan benar maka menurunkan efektivitas dari obat inhaler $\mathbf{4 , 5}$. Penelitian penggunaan inhaler pada pasien menunjukkan bahwa tidak adanya instruksi sebelumnya mengenai penggunaan inhaler dapat menyebabkan teknik penggunaan yang tidak memadai ${ }^{6}$. MDI metereddose inhaler juga inhaler yang paling banyak digunakan. Penggunaan MDI memerlukan teknik tersendiri, dimana diperlukan koordinasi yang tepat antara tangan menekan alat MDI aktuasi dan mulut menghirup obat ${ }^{\mathbf{7 , 8}}$. Kesulitan penggunaan MDI dapat diatas dengan menggunakan MDI dengan spacer ${ }^{5}$. Sebuah studi dari 23 penelitian menunjukkan prevalensi lima kali lipat kandidiasis oral pada pasien yang memakai inhalasi kortikosteroid MDI dan peningkatan tiga kali lipat pada pasien yang menggunakan DPI ${ }^{9}$. Penelitian lain 
Jurnal Insan Farmasi Indonesia, 3(2) Desember 2020 (217-229)

Amelia Lorensia

p-ISSN 2621-3184 ; e-ISSN 2621-4032

doi: $10.36387 /$ jifi.v3i2.583

oleh Ganguly et al. ${ }^{10}$ di Kolkata kota

India didapatkan hasil signifikan

kesalahan cara penggunaan inhaler

mencapai 95\%. Hal ini menunjukkan

bahwa ketepatan cara penggunaan

inhaler masih kurang akibat pasien

yang pasif dan tingkat pertukaran

informasi yang rendah selama

konsultasi ${ }^{11}$.

Dalam menggunakan alat-alat inhalasi tersebut, pasien asma membutuhkan peran farmasi komunitas di apotek yang akan sangat membantu secara signifikan dalam edukasi teknik inhalasi ${ }^{\mathbf{1 2}}$. Hubungan yang baik antara pasien dan apoteker dapat membantu pengobatan yang optimal bagi pasien dalam memahami terapi obat, mengontrol gejala asma, dan kemampuan penggunaan inhaler 13. Oleh karena itu, apoteker membutuhkan pendidikan yang tepat untuk memastikan bahwa pasien tahu bagaimana membuat penggunaan terbaik dari pengobatan mereka ${ }^{2}$. Banyak apoteker di apotek yang terlibat dalam minimnya pengetahuan dasar pasien dan keterampilan praktis yang diperlukan pasien untuk menggunakan inhalasi yang benar, yang berisiko memiliki dampak negatif serius pada pendidikan pasien dalam perawatan asma 2,14,15,16. Suatu studi oleh Baddar et al. ${ }^{\mathbf{1 6}}$, pada 150 penyedia layanan kesehatan menunjukan bahwa sebanyak 148 99\% terlibat dalam mengajar teknik inhaler untuk pasien. Namun hanya 22 peserta $15 \%$ melakukan semua langkah dengan benar. Penelitian lain yang dilakukan oleh Osman et al. ${ }^{14} \mathrm{di}$ 300 apotek di Sudan menunjukan bahwa lebih dari separuh apoteker tidak mengetahui bagaimana menggunakan MDI secara tepat.

Edukasi bagi apoteker di apotek dapat meningkatkan pengetahuan apoteker serta menunjang perbaikan outcome gejala asma pasien dengan penjelasan penggunaan inhaler secara tepat ${ }^{17,18}$. Di Indonesia, tepatnya Kota Surabaya, penelitian untuk meningkatkan pengetahuan apoteker mengenai cara penggunaan inhaler yang telah dilakukan oleh Lorensia et al. 19, dari 609 farmasis yang dikunjungi di Surabaya hanya sekitar $25 \%$ saja yang bersedia mengikuti edukasi hingga akhir. Dari permasalahan tersebut dimungkinkan 
Jurnal Insan Farmasi Indonesia, 3(2) Desember 2020 (217-229)

Amelia Lorensia

p-ISSN 2621-3184 ; e-ISSN 2621-4032

doi: 10.36387/jifi.v3i2.583

untuk dilakukan penelitian pemberian intervensi terhadap mahasiswa strata-

1 farmasi dengan menggunakan penelitian Basheti et al. ${ }^{20}$. Peran besar audio-visual dalam membantu untuk belajar dengan kecepatan mereka sendiri dan akibatnya dapat menstimulasi dalam proses belajar dan terbebas dari stress ${ }^{21}$. Tujuan dari penelitian ini adalah untuk mengetahui efektivitas pemberian edukasi dalam bentuk video dapat meningkatkan kemampuan menjelaskan cara penggunaan MDI dan MDI dengan spacer secara verbal dan motorik pada mahasiswa farmasi.

\section{METODE PENELITIAN}

\section{Populasi dan Sampel}

Populasi target yaitu mahasiswa farmasi yang melaksanakan pendidikan strata-1 di Fakultas Farmasi. Sampel dalam penelitian ini adalah mahasiswa fakultas farmasi yang aktif melaksanakan pendidikan strata-1 yang memenuhi kriteria penelitian yaitu belum pernah mengikuti pelatihan terkait cara menggunakan alat inhaler; dan tidak ada gangguan motorik. Dalam penelitian ini teknik pengambilan sampel yang digunakan yaitu purposive sampling.

Data mahasiswa yang memenuhi kriteria sebanyak 422 mahasiswa, maka dengan confidence level $95 \%$ dan margin of error sebesar 5. Maka berdasarkan rumus dibawah ini, besar sampel minimal adalah 76 orang.

$\mathrm{n}=\frac{\mathrm{p} \cdot \mathrm{q} \cdot \mathrm{N} \cdot \mathrm{z}^{2}}{\mathrm{~N} \cdot \mathrm{d}^{2}+\mathrm{p} \cdot \mathrm{q} \cdot \mathrm{z}^{2}}$

Keterangan:

$\mathrm{n}=$ Besarnya sampel.

$\mathrm{p}=\mathrm{q}=$ Proporsi untuk sifat tertentu yang diperkirakan pada populasi yaitu 0,5 .

$\mathrm{N}=$ Besarnya populasi

$\mathrm{d}=$ Derajat ketepatan yang diinginkan yaitu 0,1 .

$\mathrm{Z}=$ Standart deviasi normal sesuai dengan derajat kemaknaan $95 \%$ yaitu 1,96 .

\section{Instrumen Penelitian}

Instrumen yang digunakan pada penelitian ini terdiri dari tiga macam yaitu alat bantu berupa MDI sebagai peraga, media audio visual berupa video yang berisi materi edukasi dan checklist cara penggunaan MDI tabel 1 dan MDI dengan spacer tabel 2.

Alamat video MDI: https://youtu.be/lu51vkkRWos

Alamat video MDI dengan spacer: https://youtu.be/MnVilAz8IeE 
Tabel 1. Checklist Penilaian Cara Penggunaan MDI 22

\begin{tabular}{|c|c|c|c|c|c|}
\hline \multirow[t]{2}{*}{ No. } & \multirow{2}{*}{$\begin{array}{l}\text { Langkah-langkah } \\
\text { Penggunaan MDI }\end{array}$} & \multicolumn{2}{|l|}{ Penilaian Secara Oral } & \multicolumn{2}{|l|}{ Penilaian Secara Motorik } \\
\hline & & $\begin{array}{l}\text { Penilaian yang Dikatakan oleh } \\
\text { Subyek }\end{array}$ & Nilai: & $\begin{array}{l}\text { Penilaian yang Diperagakan oleh } \\
\text { Subyek }\end{array}$ & Nilai: \\
\hline \multirow[t]{3}{*}{1} & \multirow{3}{*}{$\begin{array}{l}\text { Buka dan lepaskan } \\
\text { penutup pada } \\
\text { mouthpiece } \mathrm{MDI} \\
\text { ujung inhaler }\end{array}$} & $\begin{array}{l}\text { Buka \& lepaskan penutup pada } \\
\text { mouthpiece ujung inhaler }\end{array}$ & 1 & $\begin{array}{l}\text { Membuka \& melepaskan penutup pada } \\
\text { mouthpiece ujung inhaler }\end{array}$ & 1 \\
\hline & & Buka / lepaskan & 0,5 & Menunjuk saja & 0,5 \\
\hline & & Tidak mengatakan apapun diam & 0 & Tidak melakukan apapun diam & 0 \\
\hline \multirow[t]{3}{*}{2} & \multirow{3}{*}{$\begin{array}{l}\text { Kocok inhaler segera } \\
\text { setiap kali sebelum } \\
\text { digunakan posisi } \\
\text { inhaler inhaler tegak, } \\
\text { kocok pelan keatas } \\
\text { dan kebawah * }\end{array}$} & $\frac{\text { Kocok inhaler secara horizontal }}{\text { keatas kebawah }}$ & 1 & $\begin{array}{l}\text { Mengocok inhaler segera setiap kali } \\
\text { sebelum digunakan posisi inhaler } \\
\text { inhaler tegak, kocok pelan keatas dan } \\
\text { kebawah }\end{array}$ & 1 \\
\hline & & $\begin{array}{l}\text { Kocok inhaler tanpa penjelasan apa- } \\
\text { apa }\end{array}$ & 0,5 & Mengocok inhaler namun tidak tepat & 0,5 \\
\hline & & Tidak mengatakan apapun diam & 0 & Tidak melakukan apapun diam & 0 \\
\hline \multirow[t]{3}{*}{3} & \multirow{3}{*}{$\begin{array}{l}\text { Buang napas penuh } \\
\text { melalui mulut }\end{array}$} & Buang napas penuh melalui mulut & 1 & Membuang napas penuh melalui mulut & 1 \\
\hline & & $\begin{array}{l}\text { Buang napas tanpa mengatakan cara } \\
\text { buang nafas melalui mulut }\end{array}$ & 0,5 & 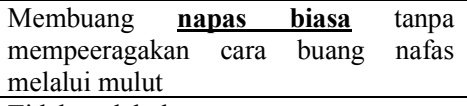 & 0,5 \\
\hline & & Tidak mengatakan apa-apa & 0 & Tidak melakukan apa-apa & 0 \\
\hline \multirow[t]{3}{*}{4} & \multirow{3}{*}{$\begin{array}{l}\text { Pegang inhaler } \\
\text { dengan posisi } \\
\text { mouthpiece di bawah } \\
\text { posisi inhaler tegak * }\end{array}$} & $\begin{array}{l}\text { Pegang inhaler dengan posisi inhaler } \\
\text { tegak \& mouthpiece di bawah }\end{array}$ & 1 & Memegang inhaler dengan posisi tegak & 1 \\
\hline & & $\begin{array}{l}\text { Pegang inhaler tanpa menjelaskan } \\
\text { secara lengkap }\end{array}$ & 0,5 & $\begin{array}{l}\text { Hanya memegang inhaler tapi posisi } \\
\text { inhaler tidak tegak }\end{array}$ & 0,5 \\
\hline & & Tidak mengatakan apapun diam & 0 & Tidak melakukan diam & 0 \\
\hline \multirow[t]{3}{*}{5} & \multirow{3}{*}{$\begin{array}{l}\text { Duduk tegak \& } \\
\text { bernafas normal }\end{array}$} & Duduk tegak \& bernafas normal & 1 & Duduk tegak \& bernafas normal & 1 \\
\hline & & Duduk tegak atau bernafas normal & 0,5 & $\begin{array}{l}\text { Hanya duduk tegak atau bernafas } \\
\text { normal }\end{array}$ & 0,5 \\
\hline & & Duduk biasa \& bernafas normal & 0 & Duduk biasa \& bernafas normal & 0 \\
\hline \multirow[t]{3}{*}{6} & \multirow{3}{*}{$\begin{array}{l}\text { Tekan bagian tabung } \\
\text { atas canister, bersama } \\
\text { dengan itu hirup } \\
\text { secara perlahan \& } \\
\text { mendalam melalui } \\
\text { mulut }\end{array}$} & $\begin{array}{l}\text { Tekan canister MDI, bersama } \\
\text { dengan itu hirup secara perlahan \& } \\
\text { mendalam melalui mulut }\end{array}$ & 1 & $\begin{array}{l}\text { Menekan canister MDI, bersama } \\
\text { dengan itu menghirup secara perlahan } \\
\text { \& mendalam melalui mulut }\end{array}$ & 1 \\
\hline & & $\begin{array}{l}\text { Tekan canister MDI dan hirup tanpa } \\
\text { menjelaskan secara lengkap }\end{array}$ & 0,5 & $\begin{array}{l}\text { Menekan canister MDI dan hirup tidak } \\
\text { memperagakan secara lengkap }\end{array}$ & 0,5 \\
\hline & & Tidak mengatakan apapun diam & 0 & Tidak melakukan apapun diam & 0 \\
\hline \multirow[t]{3}{*}{7} & \multirow[t]{3}{*}{$\begin{array}{l}\text { Tahan napas selama } \\
\text { maksimal } 10 \text { detik }\end{array}$} & $\begin{array}{l}\text { Tahan napas maksimal selama } 10 \\
\text { detik, Apabila tidak bisa selama } 10 \\
\text { detik dapat menahan nafas sebisa } \\
\text { mungkin }\end{array}$ & 1 & $\begin{array}{l}\text { Menahan napas dan memperagakan } \\
\text { sambil dalam posisi tegak }\end{array}$ & 1 \\
\hline & & $\begin{array}{l}\text { Tahan napas menjelaskan namun } \\
\text { kurang lengkap/pas }\end{array}$ & 0,5 & $\begin{array}{l}\text { Menahan napas memperagakan namun } \\
\text { kurang lengkap/pas }\end{array}$ & 0,5 \\
\hline & & Tidak mengatakan apapun diam & 0 & Tidak menahan napas & 0 \\
\hline \multirow[t]{3}{*}{8} & \multirow{3}{*}{$\begin{array}{l}\text { Kumur mulut anda } \\
\text { dengan air dan buang } \\
\text { jangan ditelan * }\end{array}$} & $\begin{array}{l}\text { Kumur mulut anda dengan air dan } \\
\text { membuang air kumur }\end{array}$ & 1 & $\begin{array}{l}\text { Memperagakan berkumur dengan air } \\
\text { dan buang air tersebut }\end{array}$ & 1 \\
\hline & & $\begin{array}{l}\text { Kumur dengan air tidak menjelaskan } \\
\text { untuk dibuang }\end{array}$ & 0,5 & $\begin{array}{l}\text { Memperagakan berkumur dengan air } \\
\text { namun tidak memperagakan untuk } \\
\text { buang air }\end{array}$ & 0,5 \\
\hline & & Tidak mengatakan apapun diam & 0 & Tidak melakukan apapun diam & 0 \\
\hline
\end{tabular}

Tabel 2. Checklist Penilaian Cara Penggunaan MDI dengan Spacer 5

\begin{tabular}{|c|c|c|c|c|c|}
\hline \multirow[t]{2}{*}{ No. } & \multirow{2}{*}{$\begin{array}{l}\text { Langkah-langkah } \\
\text { Penggunaan MDI } \\
\text { dengan Spacer }\end{array}$} & \multicolumn{2}{|l|}{ Penilaian Secara Oral } & \multicolumn{2}{|l|}{ Penilaian Secara Motorik } \\
\hline & & $\begin{array}{l}\text { Penilaian yang Dikatakan oleh } \\
\text { Subyek }\end{array}$ & Nilai: & $\begin{array}{c}\text { Penilaian yang Diperagakan oleh } \\
\text { Subyek } \\
\end{array}$ & Nilai: \\
\hline \multirow[t]{3}{*}{1} & \multirow{3}{*}{$\begin{array}{l}\text { Buka dan lepaskan } \\
\text { penutup pada } \\
\text { mouthpiece MDI ujung } \\
\text { inhaler }\end{array}$} & $\begin{array}{l}\text { Buka \& lepaskan penutup pada } \\
\text { mouthpiece ujung inhaler }\end{array}$ & 1 & $\begin{array}{l}\text { Membuka \& melepaskan penutup pada } \\
\text { mouthpiece ujung inhaler }\end{array}$ & 1 \\
\hline & & Buka / lepaskan & 0,5 & Menunjuk saja & 0,5 \\
\hline & & Tidak mengatakan apapun diam & 0 & Tidak melakukan apapun diam & 0 \\
\hline \multirow[t]{3}{*}{2} & \multirow{3}{*}{$\begin{array}{l}\text { Kocok inhaler segera } \\
\text { setiap kali sebelum } \\
\text { digunakan posisi } \\
\text { inhaler inhaler tegak, } \\
\text { kocok pelan keatas } \\
\text { dan kebawah * }\end{array}$} & $\begin{array}{l}\text { Kocok inhaler secara vertikal keatas } \\
\text { kebawah }\end{array}$ & 1 & $\begin{array}{l}\text { Mengocok inhaler segera setiap kali } \\
\text { sebelum digunakan posisi inhaler inhaler } \\
\text { tegak, kocok pelan keatas dan kebawah }\end{array}$ & 1 \\
\hline & & Kocok inhaler tanpa penjelasan & 0,5 & Mengocok inhaler namun tidak tepat & 0,5 \\
\hline & & Tidak mengatakan apapun diam & 0 & Tidak melakukan apapun diam & 0 \\
\hline 3 & & Buang napas penuh melalui mulut & 1 & Membuang napas penuh melalui mulut & 1 \\
\hline
\end{tabular}


Jurnal Insan Farmasi Indonesia, 3(2) Desember 2020 (217-229)

Amelia Lorensia

p-ISSN 2621-3184 ; e-ISSN 2621-4032

doi: 10.36387/jifi.v3i2.583

\begin{tabular}{|c|c|c|c|c|c|}
\hline \multirow[t]{4}{*}{ No. } & \multirow{4}{*}{$\begin{array}{l}\text { Langkah-langkah } \\
\text { Penggunaan MDI } \\
\text { dengan Spacer } \\
\text { Buang napas penuh } \\
\text { melalui mulut }\end{array}$} & \multicolumn{2}{|l|}{ Penilaian Secara Oral } & \multicolumn{2}{|l|}{ Penilaian Secara Motorik } \\
\hline & & \multirow{2}{*}{$\begin{array}{l}\text { Penilaian yang Dikatakan oleh } \\
\text { Subyek } \\
\begin{array}{l}\text { Buang napas tanpa mengatakan cara } \\
\text { buang nafas melalui mulut }\end{array}\end{array}$} & \multirow{2}{*}{ Nilai: } & $\begin{array}{l}\text { Penilaian yang Diperagakan oleh } \\
\text { Subyek }\end{array}$ & Nilai: \\
\hline & & & & 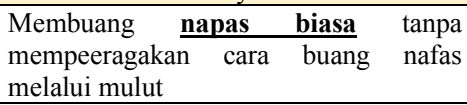 & 0,5 \\
\hline & & Tidak mengatakan apa-apa & 0 & Tidak melakukan apa-apa & 0 \\
\hline \multirow[t]{3}{*}{4} & \multirow{3}{*}{$\begin{array}{l}\text { Pegang inhaler dengan } \\
\text { posisi mouthpiece di } \\
\text { bawah posisi inhaler } \\
\text { tegak * }\end{array}$} & $\begin{array}{l}\text { Pegang inhaler dengan posisi inhaler } \\
\text { tegak \& mouthpiece di bawah }\end{array}$ & 1 & $\begin{array}{l}\text { Memegang inhaler dengan posisi tegak } \\
\text { \& benar }\end{array}$ & 1 \\
\hline & & Pegang inhaler tanpa penjelasan lain & 0,5 & $\begin{array}{l}\text { Hanya memegang inhaler tapi posisi } \\
\text { inhaler tidak tegak }\end{array}$ & 0,5 \\
\hline & & Tidak mengatakan apapun diam & 0 & Tidak melakukan diam & 0 \\
\hline \multirow[t]{3}{*}{5} & \multirow{3}{*}{$\begin{array}{l}\text { Pasang spacer pada } \\
\text { inhaler }\end{array}$} & Pasang spacer pada inhaler & 1 & Memasang spacer pada inhaler & 1 \\
\hline & & $\begin{array}{l}\text { Pasang spacer pada inhaler namun } \\
\text { penjelasan kurang tepat }\end{array}$ & 0,5 & $\begin{array}{l}\text { Memasang spacer ke inhaler namun } \\
\text { kurang tepat }\end{array}$ & 0,5 \\
\hline & & Tidak mengatakan apapun diam & 0 & Tidak melakukan apapun diam & 0 \\
\hline \multirow[t]{3}{*}{6} & \multirow[t]{3}{*}{$\begin{array}{l}\text { Tempatkan corong } \\
\text { spacer * }\end{array}$} & $\begin{array}{l}\text { Tempatkan corong spacer menutupi } \\
\text { bagian hidung dan mulut }\end{array}$ & 1 & $\begin{array}{l}\text { Menempatkan corong spacer menutupi } \\
\text { bagian hidung dan mulut }\end{array}$ & 1 \\
\hline & & $\begin{array}{l}\text { Tempatkan corong spacer namun } \\
\text { penjelasan kurang tepat }\end{array}$ & 0,5 & $\begin{array}{l}\text { Menempatkan corong spacer namun } \\
\text { kurang tepat }\end{array}$ & 0,5 \\
\hline & & Tidak mengatakan apapun diam & 0 & Tidak melakukan apapun diam & 0 \\
\hline \multirow[t]{3}{*}{7} & \multirow{3}{*}{$\begin{array}{l}\text { Duduk tegak \& } \\
\text { bernafas normal }\end{array}$} & Duduk tegak \& bernafas normal & 1 & Duduk tegak \& bernafas normal & 1 \\
\hline & & Duduk tegak atau bernafas normal & 0,5 & Hanya duduk tegak atau bernafas normal & 0,5 \\
\hline & & Duduk biasa \& bernafas normal & 0 & Duduk biasa \& bernafas normal & 0 \\
\hline \multirow[t]{4}{*}{8} & \multirow{4}{*}{$\begin{array}{l}\text { Tekan bagian tabung } \\
\text { atas canister, bersama } \\
\text { dengan itu hirup } \\
\text { secara perlahan \& } \\
\text { mendalam melalui } \\
\text { mulut }\end{array}$} & Tekan canister MDI, bersama & & Menekan canister MDI, bersama & \\
\hline & & $\begin{array}{l}\text { dengan itu hirup secara perlahan } \& \\
\text { mendalam melalui mulut }\end{array}$ & 1 & $\begin{array}{l}\text { dengan itu menghirup secara perlahan } \\
\& \text { mendalam melalui mulut }\end{array}$ & 1 \\
\hline & & $\begin{array}{l}\text { Tekan canister } \overline{\text { MDI dan hirup }} \\
\text { menjelaskan namun kurang tepat }\end{array}$ & 0,5 & $\begin{array}{l}\text { Menekan canister MDI dan hirup } \\
\text { memperagakan namun kurang tepat }\end{array}$ & 0,5 \\
\hline & & Tidak mengatakan apapun diam & 0 & Tidak melakukan apapun diam & 0 \\
\hline \multirow[t]{3}{*}{9} & \multirow{3}{*}{$\begin{array}{l}\text { Tahan napas selama } \\
10 \text { detik, kemudian } \\
\text { hembuskan secara } \\
\text { perlahan melalui } \\
\text { mulut }\end{array}$} & $\begin{array}{l}\text { Tahan napas maksimal selama } 10 \\
\text { detik, apabila tidak bisa selama } 10 \\
\text { detik dapat menahan nafas sebisa } \\
\text { mungkin }\end{array}$ & 1 & $\begin{array}{ll}\text { - } & \text { Menahan napas } \\
\text { - } & \text { Memperagakan sambil dalam posisi } \\
\text { tegak }\end{array}$ & 1 \\
\hline & & $\begin{array}{l}\text { Tahan napas menjelaskan namun } \\
\text { kurang tepat }\end{array}$ & 0,5 & $\begin{array}{l}\text { Menahan napas memperagakan namun } \\
\text { kurang tepat }\end{array}$ & 0,5 \\
\hline & & Tidak mengatakan apapun diam & 0 & Tidak menahan napas & 0 \\
\hline \multirow[t]{3}{*}{10} & \multirow{3}{*}{$\begin{array}{l}\text { Lepas spacer \& tutup } \\
\text { kembali bagian ujung } \\
\text { inhaler mouthpiece }\end{array}$} & $\begin{array}{l}\text { Lepas spacer \& tutup kembali bagian } \\
\text { ujung inhaler mouthpiece }\end{array}$ & 1 & $\begin{array}{l}\text { Melepas spacer \& tutup kembali bagian } \\
\text { ujung inhaler mouthpiece }\end{array}$ & 1 \\
\hline & & $\begin{array}{l}\text { Lepas spacer/tutup bagian ujung } \\
\text { inhaler mouthpiece saja }\end{array}$ & 0,5 & $\begin{array}{l}\text { Melepas spacer/tutup bagian ujung } \\
\text { inhaler mouthpiece saja }\end{array}$ & 0,5 \\
\hline & & Tidak mengatakan & 0 & Tidak melakukan & 0 \\
\hline \multirow[t]{3}{*}{11} & \multirow{3}{*}{$\begin{array}{l}\text { Kumur mulut anda } \\
\text { dengan air dan buang } \\
\text { jangan ditelan * }\end{array}$} & $\begin{array}{l}\text { Kumur mulut anda dengan air dan } \\
\text { buang }\end{array}$ & 1 & Berkumur dengan air dan buang & 1 \\
\hline & & Kumur dengan air dan tidak dibuang & 0,5 & Berkumur dengan air dan tidak dibuang & 0,5 \\
\hline & & Tidak mengatakan apapun diam & 0 & Tidak berkumur & 0 \\
\hline
\end{tabular}

\section{Metode Pengumpulan Data}

a. Penyusunan check list dan pembuatan video Edukasi. Video edukasi dibuat dengan konsep satu orang berperan sebagai apoteker pemberi edukasi dan satu orang lagi berperan sebagai pasien yang diberikan edukasi. b. Validasi Video Edukasi . Validasi isi adalah untuk memeriksa kembali apakah isi dari media edukasi sesuai materi edukasi dan tujuan yang akan diukur, dibuat jelas dan mudah serta menarik untuk subyek dan susunan atau langkah-langkah dari check list. Sedangkan validasi konstruk 
Jurnal Insan Farmasi Indonesia, 3(2) Desember 2020 (217-229)

Amelia Lorensia

p-ISSN 2621-3184 ; e-ISSN 2621-4032

doi: 10.36387/jifi.v3i2.583

dilakukan dengan melakukan

kemampuan subyek dalam wawancara pada mahasiswa farmasi yang tidak terlibat sebagai subyek penelitian sebanyak 30 orang.

c. Validasi Interrater. Interrater adalah penilai dan 1 mahasiswa fakultas farmasi semester atas/akhir dan sudah mengambil mata kuliah terkait cara penggunaan inhaler. Reliabilitas antar penilai adalah ukuran reliabilitas berdasarkan konsistensi penilaian dua responden berbeda terhadap suatu konstruk, karena belum tentu pengamat manusia menafsirkan jawaban dengan cara yang sama. Uji reliabilitas interrater cara penggunaan MDI check list menggunakan Cohen's Kappa. Dinyatakan reliabel jika nilai Cohen's Kappa $>0,6$.

d. Pengambilan Data Pre-test, Edukasi, dan Post-test.

\section{$\underline{\text { Analisis Data }}$}

Penelitian ini menggunakan analisa deskriptif. Data yang telah diperoleh kemudian dievaluasi berdasarkan dengan checklist dan dievaluasi berdasarkan dengan nilai tiap step dan total score, dari kemampuan subyek dalam

HASIL DAN PEMBAHASAN

$\underline{\text { Pelaksanaan Penelitian }}$

Penelitian dilaksanakan di fakultas farmasi suatu universitas swasta di Surabaya, dengan jumlah kelompok MDI sebanyak 85 orang dan kelompok MDI dengan spacer sebanyak 84 orang.

\section{Karakteristik Subyek Penelitian}

mengucapkan tiap step verbal; yang paling banyak berpartisipasi 
Jurnal Insan Farmasi Indonesia, 3(2) Desember 2020 (217-229)

Amelia Lorensia

p-ISSN 2621-3184 ; e-ISSN 2621-4032

doi: 10.36387/jifi.v3i2.583

adalah perempuan dengan latar pernah bekerja di apotek dan rumah belakang pendidikan SMA sekolah sakit tidak pernah ada pengalaman menengah atas. Beberapa subjek yang menjelaskan inhaler Tabel 3.

Tabel 3. Karakteristik Subyek Penelitian

\begin{tabular}{|c|c|c|c|c|c|}
\hline \multirow{2}{*}{\multicolumn{2}{|c|}{ Karakteristik }} & \multicolumn{2}{|c|}{$\begin{array}{c}\text { Kelompok MDI } \\
\text { n: } 85\end{array}$} & \multicolumn{2}{|c|}{$\begin{array}{c}\text { Kelompok MDI } \\
\text { dengan Spacer n: } \\
84\end{array}$} \\
\hline & & n: & $\begin{array}{c}\text { Persentase } \\
\%\end{array}$ & n: & $\begin{array}{c}\text { Persentase } \\
\%\end{array}$ \\
\hline \multirow[t]{2}{*}{ Jenis Kelamin } & Laki-laki & 10 & 11,8 & 14 & 16,67 \\
\hline & Perempuan & 75 & 85,2 & 70 & 83,33 \\
\hline \multirow{3}{*}{$\begin{array}{l}\text { Pendidikan } \\
\text { sebelumnya }\end{array}$} & SMA Sekolah Menengah Atas & 50 & 56,8 & 74 & 88,10 \\
\hline & AA Asisten Apoteker & 7 & 8,2 & 2 & 2,38 \\
\hline & SMF Sekolah Menengah Farmasi & 28 & 32,9 & 8 & 9,53 \\
\hline \multirow{2}{*}{$\begin{array}{l}\text { Pernah bekerja di... } \\
\text { tidak pernah ada pengalaman } \\
\text { menjelaskan inhaler }\end{array}$} & Apotek & 4 & 4,7 & 2 & 2,38 \\
\hline & Rumah sakit & 3 & 3,5 & $\mathbf{0}$ & 0 \\
\hline
\end{tabular}

\section{Validasi Checklist dan Video MDI}

Validasi checklist dalam penelitian ini dilakukan untuk menyamakan persepsi antar interrater yaitu arti dan penilaian dari setiap step pada checklist antar per-reviewer yang menilai pada saat subyek memperagakan cara penggunaan MDI dan MDI dengan spacer. Uji reliabilitas pada penelitian ini menggunakan Cohen's Kappa dengan nilai yang didapat adalah $0,615>0,6$ maka nilai koefisien kappa menunjukkan adanya korelasi atau penilaian antar rater tidak terjadi perbedaan.

Kelengkapan Informasi Cara Penggunaan MDI
Berdasarkan Tabel 4, menggambarkan jumlah subyek berdasarkan total score. Setelah edukasi, sebagian besar subjek mendapatkan nilai tertinggi.

$$
\text { Langkah membuka dan }
$$
melepaskan penutup pada mouthpiece MDI pada step ini apabila tidak dilakukan maka tidak dapat dipakai secara cepat karena dosis pada saat terjadi eksaserbasi asma tidak dapat keluar dari mouthpiece MDI 5,14. Pada step ini sebagian besar subyek hanya memperagakan motorik namun tidak mengucapkan verbal. Pada saat akan menjelaskan alat, subyek langsung membuka penutup MDI tanpa 
Jurnal Insan Farmasi Indonesia, 3(2) Desember 2020 (217-229)

Amelia Lorensia

p-ISSN 2621-3184 ; e-ISSN 2621-4032

doi: $10.36387 /$ jifi.v3i2.583

mengucapkan bahwa penutup MDI dapat mengangkat partikel sehingga harus dibuka terlebih dahulu.

Tahapan membuang nafas penuh melalui mulut membantu mempersiapkan menarik nafas dalam dan sekuat mungkin supaya dapat menciptakan aliran turbulen yang obat akan langsung terdeposisi ke bronkiolus 5,14,23. Pada step 3 ini kriteria untuk menghembuskan napas adalah bahwa subyek harus memperagakan menghembuskan napas pernuh melalui mulut.

Tabel 4. Distribusi Frekuensi Jumlah Subyek Berdasarkan Total Score

\begin{tabular}{|c|c|c|c|c|c|c|c|c|c|c|c|c|}
\hline \multirow{4}{*}{$\begin{array}{l}\text { Total } \\
\text { Score }\end{array}$} & \multicolumn{12}{|c|}{ Jumlah Subjek Penelitian } \\
\hline & \multicolumn{6}{|c|}{ Kelompok MDI n: 85} & \multicolumn{6}{|c|}{ Kelompok MDI dengan Spacer n: 84} \\
\hline & \multicolumn{3}{|c|}{ Pre-test } & \multicolumn{3}{|c|}{ Post-test } & \multicolumn{3}{|c|}{ Pre-test } & \multicolumn{3}{|c|}{ Post-test } \\
\hline & $\mathbf{V}$ & $\mathbf{M}$ & $\mathbf{V}+\mathbf{M}$ & $\mathbf{V}$ & $\mathbf{M}$ & $\mathbf{V}+\mathbf{M}$ & $\mathbf{V}$ & $\mathbf{M}$ & $\mathbf{V}+\mathbf{M}$ & $\mathbf{V}$ & $\mathbf{M}$ & $\mathbf{V}+\mathbf{M}$ \\
\hline $\mathbf{0}$ & 85 & 85 & 85 & 0 & 0 & 0 & 84 & 84 & 84 & 0 & 0 & 0 \\
\hline 6,0 & 0 & 0 & 0 & 0 & 10 & 0 & 0 & 0 & 0 & 0 & 0 & 0 \\
\hline 6,5 & 0 & 0 & 0 & 2 & 15 & 0 & 0 & 0 & 0 & 0 & 0 & 0 \\
\hline 7,0 & 0 & 0 & 0 & 13 & 1 & 3 & 0 & 0 & 0 & 1 & 0 & 0 \\
\hline 7,5 & 0 & 0 & 0 & 28 & 2 & 25 & 0 & 0 & 0 & 2 & 0 & 0 \\
\hline 8,0 & 0 & 0 & 0 & 42 & 57 & 57 & 0 & 0 & 0 & 3 & 0 & 0 \\
\hline 8,5 & & & & & & & 0 & 0 & 0 & 10 & 0 & 0 \\
\hline 9,0 & & & & & & & 0 & 0 & 0 & 5 & 2 & 0 \\
\hline 9,5 & & & & & & & 0 & 0 & 0 & 8 & 0 & 0 \\
\hline 10,0 & & & & & & & 0 & 0 & 0 & 11 & 6 & 19 \\
\hline 10,5 & & & & & & & 0 & 0 & 0 & 4 & 8 & 25 \\
\hline 11,0 & & & & & & & 0 & 0 & 0 & 40 & 68 & 40 \\
\hline $\mathrm{V}$ & en & 111 & a ver & H & aka & & & & & & & \\
\hline M & pen & in $\mathrm{s}$ & ra mo & $\mathrm{k} \mathrm{n}$ & 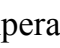 & $\operatorname{ran}$ & & & & & & \\
\hline $\mathrm{V}+\mathrm{M}$ & & an $\mathrm{s}$ & ra ver & $\mathrm{me}$ & 1 & an $n$ & $\mathrm{k} \mathrm{n}$ & iper & akan & & & \\
\hline
\end{tabular}

Pentingnya memperhatikan posisi canister MDI karena apabila posisi canister terbalik maka dapat mengurangi efektifitas obat yang berkaitan dengan gaya gravitasi pada distribusi ukuran partikel optimum untuk sebagian besar aerosol inhalasi secara umum telah diakui sebagai berada di kisaran 1-5 $\mu \mathrm{m}^{\mathbf{1 4}}$. Kesulitan penilaian pada step ini yaitu beberapa subyek lupa pada posisi tangan saat memegang MDI.

Langkah kumur mulut anda dengan air dan buang. Tujuan dari step ini untuk membasuh apapun partikel obat yang tidak dihirup ke dalam paruparu dan mungkin tetap berada di tenggorokan. Berkumur dapat menurunkan resiko sariawan atau suara serak 24,25. Mayoritas subyek 
Jurnal Insan Farmasi Indonesia, 3(2) Desember 2020 (217-229)

Amelia Lorensia

p-ISSN 2621-3184 ; e-ISSN 2621-4032

doi: 10.36387/jifi.v3i2.583

tidak mengatakan dan memperagakan

Kolmogrov-sminorv test yang step ini setelah menggunakan inhaler, padahal sebaiknya menjaga digunakan untuk mengetahui apakah kebersihan mulut yakni dengan membilas, berkumur dan membuang sisa kumur setelah penggunaan inhaler dapat menurunkan resiko sariawan atau suara serak yang disebabkan oleh obat-obatan yang mungkin masih tertinggal di mulut ${ }^{3}$. Kesulitan pada step sebagian besar subyek lupa untuk memperagakan dan mengatakan karena tidak tersedianya alat untuk berkumur. Dengan berkumur membantu menurunkan resiko sariawan atau suara serak.

Pada kelompok MDI dan MDI dengan spacer, awal pengujian data diuji normalitasnya menggunakan data berdistribusi normal atau tidak. Data dikatakan berdistribusi normal apabila $\geq 0,05$. Hasil penelitian ini menyatakan bahwa data pre-test tidak terdistribusi normal p0,000<0,05 sehingga tidak dapat dilakukan analisis parametri. Sedangkan data post-test terdistribusi normal p0,060>0,05. Berdasarkan hasil penelitian, pengolahan data pada penelitian ini menggunakan analisis non-parametrik yang bertujuan untuk mengetahui pengaruh antara variabel bebas dan variabel terikat, yaitu dengan menggunakan uji nonparametrik Wilcoxon signed rank test untuk data ordinal Tabel 6.

Tabel 6. Uji Beda pada Kelompok MDI dan MDI dengan Spacer

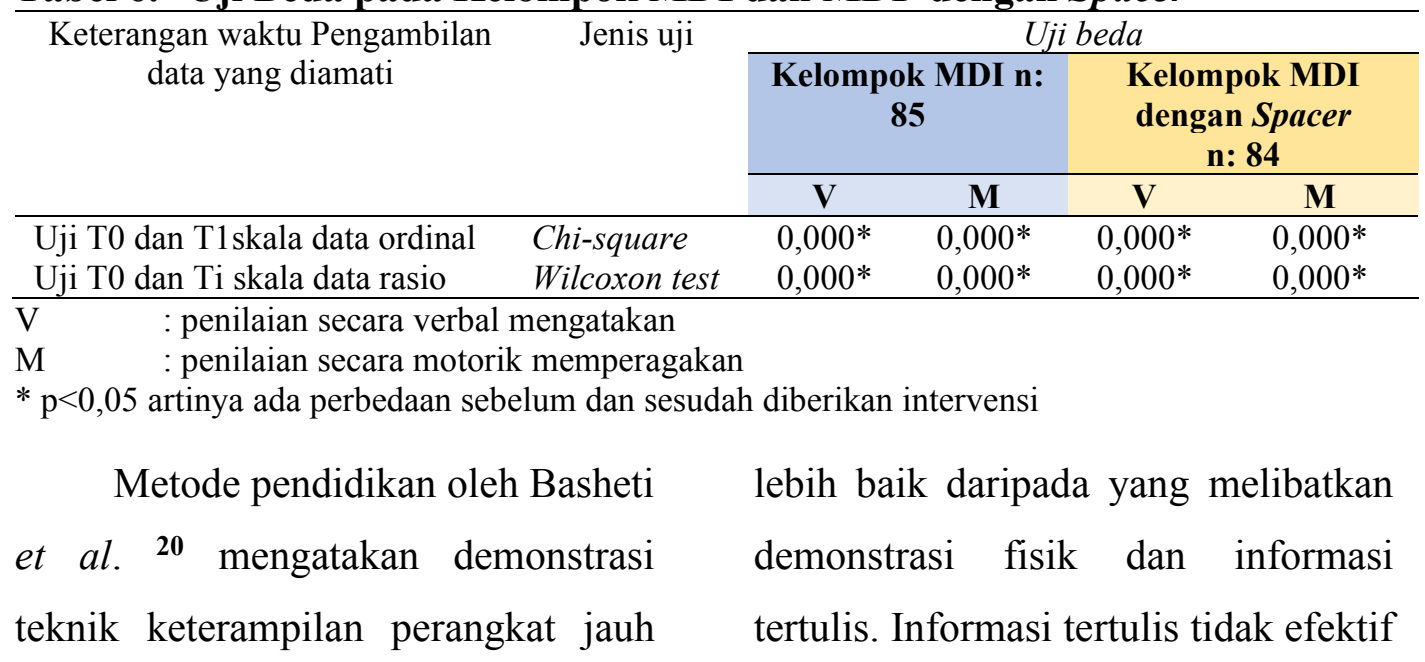


Jurnal Insan Farmasi Indonesia, 3(2) Desember 2020 (217-229)

Amelia Lorensia

p-ISSN 2621-3184 ; e-ISSN 2621-4032

doi: 10.36387/jifi.v3i2.583

dalam mengkoreksi teknik alat inhalasi pasien, siswa, atau apoteker 26,27,28. Penggunaan media dalam pembelajaran merupakan saran penunjang yang dapat meningkatkan efisiensi dan efeketifitas keberhasilan pembelajaran seperti yang diungkapkan Smaldino $^{29}$ yaitu teknologi dan media yang disesuaikan dan dirancang secara khusus bisa memberi kontribusi bagi pengajaran yang efektif dari seluruh siswa dan bisa membantu mereka meraih potensi tertinggi mereka. Pemberian video edukasi berisi tentang step cara penggunaan $\mathrm{MDI}^{\mathbf{3 0}}$ mengatakan penggunaan video edukasi mengalami peningkatan yang siginfikan dibandingkan dengan penggunaan intruksi tertulis pada step penggunaan MDI.

\section{KESIMPULAN}

Edukasi video efektif dalam meningkatkan kelengkapan penjelasan cara penggunaan MDI $\mathrm{p}=0,000$ dan MDI dengan spacer $\mathrm{p}=0,000$.

\section{DAFTAR PUSTAKA}

1. Global Initiative for Asthma. 2019. Global Strategy for Asthma Management and Prevention online, Available at:

https://ginasthma.org/reports/201 9-gina-report-global-strategy-forasthma-management-andprevention/ [diakses 1 Maret 2019].

2. Odili, V.U., Okoribe, C.O. 2010. Assessment of Pharmacists' knowledge on correct inhaler technique. Research Journal of Pharmaceutical, Biological and Chemical Sciences, 13.pp.768-72.

3. National Asthma Council Australia, 2008, Inhaler technique in adultswith asthma or COPD online.

4. Lalani, N.S. 2012. A study of knowledge assessment and competence in asthma and inhaler technique of nurses employed at university teaching hospital, theHealth, 31: 16-8.

5. Lorensia, A., Suryadinata, R.V. 2018. Panduan Lengkap Penggunaan Macam-Macam Alat Inhaler pada Gangguan Pernafasan, CV M-Brothers Indonesia, Surabaya.

6. Lee, S.M., Chang, Y.S., Kim, C.W., Kim, T.B., Kim, S.H., Kwon, Y.E., Lee, J.M., Lee, S.K., Jeong, J.W., Park, J.W., Cho, S.H., Moon, H.B., Jee, Y.K. 2011. Skills in Handling Turbuhaler, Diskus, and Pressurized MeteredDose Inhaler in Korean Asthmatic Patients, Allergy Asthma Immunol Res, 31:46-52.

7. Al-Showair, R. A., Pearson, S. B. \& Chrystyn, H. 2007. The Potential of a 2 Tone trainer to help patiens use their metereddoseinhaler, Chest, 1316: 1776-82. 
Jurnal Insan Farmasi Indonesia, 3(2) Desember 2020 (217-229)

Amelia Lorensia

p-ISSN 2621-3184 ; e-ISSN 2621-4032

doi: 10.36387/jifi.v3i2.583

8. Bartolo, K., Balzan, M., Schembri, E.L., Asciak, R., Balbi, D.M., Bardon, M.P., Montefort, S. 2017. Predictors of correct technique in patients using pressurized metered dose inhalers, BMC Pulm Med, 171:47.

9. Rachelefsky, G.S., Liao, Y., Faruqi, R. 2007. Impact of inhaled corticosteroid-induced

oropharyngeal adverse events: results from a meta-analysis, Ann Allergy Asthma Immunol, 983:225-38.

10. Ganguly, A., Das, A.K., Roy, A., Adhikari, A., Banerjee, J., Sen, S. 2018. Study of Proper use of Inhalational Devices by Bronchial Asthma or COPD Patients Attending a Tertiary Care Hospital, J Clin Diagn Res, 810: HC04-7.

11. Melani, A.S., Bonavia, M., Cilenti, V., Cinti, C., Lodi, M., Martucci, P., Serra, M., Scichilone, N., Sestini, P., Aliani, M., Neri, M. 2011. Inhaler Mishandling Remains Common in Real life and is Associated with Reduced Disese Control, Respiratory Medicine, 1056:930-8.

12. Hämmerlein, A., Muller, U., Schulz, M. 2010. Pharmacist-led intervention study to improve inhalation technique in asthma and COPD patients, Journal of Evaluation in Clinical Practice, P1-10.

13. Onda, M., Sakurai, H., Hayase, Y., Sakamaki, H., Arakawa, Y., Yasukawa, F. 2009. Effects of Patient-Pharmacist

Communication on the Treatment of Asthma, Yakugaku Zasshi, 1294:427-33.

14. Osman, A., Hassan, I.S.A., Ibrahim, M.I.M. 2012. Are Sudanese community pharmacists capableto prescribe and demonstrate asthma inhaler devices to patrons? A mystery patient study, Pharmacy Practice, 102:110-115.

15. Nadi, E., Zeraati, F. 2005. Evaluation of the Metered-Dose Inhaler Technique Among Healthcare Providers, Acta Medica Iranica, 434: 268-72.

16. Baddar, S.A., Al-Rawas, O.A., Al-Riyami, K.A., Worthing, E.A., Hanssens, Y.I., Taqi, A.M., AlRiyami, B.M.S. 2001. Metereddose inhaler technique among healthcare providers practising in Oman, Squ journal for scientific research: Medical Sciences, 1: 39-43.

17. Cain, W.T., Cable, G., Oppenheimer, J.J. 2001. The ability of the community pharmacist to learn the proper actuation techniques of inhaler devices, Journal of Allergy and Clinical Immunology, 1086: 918-20.

18. Jackevicius, C.A., Chapman, K.R. 1999. Inhaler education for hospital-based pharmacists: how much is required?, Canadian Respiratory Journal, 63: 237-244.

19. Lorensia, A., Setiawan, B., Maranatha, D., Yudiarso, A. 2017. Effectiveness of Education Based Information-MotivationBehavioral Skill IMB Model of Improving

Knowledge, 
Jurnal Insan Farmasi Indonesia, 3(2) Desember 2020 (217-229)

Amelia Lorensia

p-ISSN 2621-3184 ; e-ISSN 2621-4032

doi: $10.36387 /$ jifi.v3i2.583

Motivation, and Performance
Demonstration Metered-Dose
Inhaler MDI to Community
Pharmacists in Surabaya,
International Journal of
Pharmaceutical and Clinical
Research IJPCR, 97: 485-495.

20. Basheti, I.A., Natsheh, A.I., Ammari, W.G., Khater, S., Qunaibi, E.A., Bosnic, S.Z. 2015. Education on Correct Inhaler Technique in Pharmacy Schools: Barriers and Needs, Trop $J$ Pharm Res, 144: 715.

21. Secer, S.Y.E., Sahin, M., Alci, B. 2015. Investigating the Effect of Audio Visual Materials as Warmup Activity in Aviation English Courses on Students' Motivation and Participation at High School Level, Social and Behavioral Sciences, 199:120-8.

22. Lorensia, A., Nathania, J. 2017. Studi Kelengkapan Penjelasan Informasi Cara Penggunaan Controller Metered-Dose Inhaler MDI yang Mengandung Kortikosteroid sebagai Terapi Asma di Apotek Kabupaten Tuban, Jurnal Ilmiah Manuntung, 31: 14-25.

23. Wahida, A., Chrystyn, H. 2012. Clarifying the dilemmas about inhalation techniques for $d r y$ powder inhalers: integrating science with clinical practice, Prim Care Respir J, 212:208-13.

24. Levy, M.L., Dekhuijzen, P.N.R., Barnes, P.J., Broeders, M., Corrigan, C.J., Chawes, B.L., Corbetta, L., Dubus, J.C., Hausen, T., Lavorini, F., Roche, N., Sanchis, J., Usmani, O.S., Viejo,
J., Vincken, W., Voshaar, T., Crompton, G.K., Pedersen, S. 2016, Inhaler technique: facts and fantasies. A view from the Aerosol Drug Management Improvement Team ADMIT, NPJ Prim Care Respir Med, 26:16028.

25. Godara, N., Godara, R., Khullar, M. 2011. Impact of inhalation therapy on oral health, Lung India, 284:272-5.

26. Horntvedt, M.T., Nordsteien, A., Fermann, T., Severinsson, E. 2018. Strategies for teaching evidence-based practice in nursing education: a thematic literature review,. BMC Med Educ, 181:172.

27. Safazadeh, S., Irajpour, A., Alimohammadi, N., Haghani, F. 2018. Exploring the reasons for theory-practice gap in emergency nursing education: A qualitative research, J Educ Health Promot, 7:132.

28. Salifu, D.A., Gross, J., Salifu, M.A., Ninnoni, J.P. 2018. Experiences and perceptions of the theory-practice gap in nursing in a resource-constrained setting: A qualitative description study, Nurs Open, 61:72-83.

29. Smaldino, S.E.L., Deborah L., Russel, J.D. 2012. Instructional Technology and Media For learning Tent Edition. Pearson Education Inc, United States of America.

30. Shah, R.F., Gupta, R.M. 2017. Video instruction is more effective than written instruction in improving inhaler technique, Pulm Pharmacol Ther, 46:16-9. 